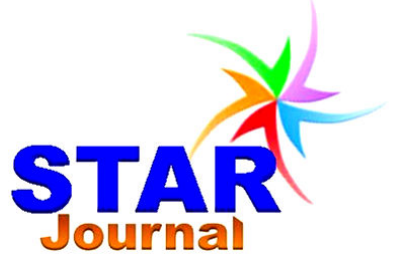

ISSN: 2226-7522(Print) and 2305-3327 (Online) Science, Technology and Arts Research Journal April-June 2013, 2(2): 148-152 www.starjournal.org Copyright@2013 STAR Journal. All Rights Reserved

\title{
ATM: The New Horizon of E-Banking
}

\author{
Sabita Paul
}

Department of Economics, Noesis College, Hyderabad, India

\begin{tabular}{|c|c|}
\hline & Article Inf \\
\hline \multirow{4}{*}{$\begin{array}{l}\text { In today's world, technology has been used as strategy to win market and customers, which } \\
\text { has changed the pattern of almost all the organizations in performing their business. The } \\
\text { Indian banking industry is not an exception of it. With the advent and application of } \\
\text { Information Technology (IT) the banking sector is becoming more and more innovative } \\
\text { delivering a good competitive and better Service Quality (SQ) to their customers. It puts both } \\
\text { the banks and the customers in a win-win situation. The present study aims at understanding } \\
\text { the role of ATM (Automated Teller Machine ) and its influence on the service quality level } \\
\text { provided by various commercial banks in Odisha, and the paper concludes that ATM has } \\
\text { become an integral part to the customers in the banking industry and it will continue as more } \\
\text { progress and innovations are made in IT sector. It is mainly based on data, collected from the } \\
\text { banking customers in different commercial banks of Odisha. Hence the findings of this } \\
\text { research will help the banks in Ethiopia also to establish a customer oriented strategy to } \\
\text { retain their customers' satisfaction in future. The methodologies used for this research } \\
\text { involved interviews with bank customers and bank managers of the case study banks and } \\
\text { administrations of questionnaires to a number of bank customers in Odisha. To investigate in } \\
\text { the real-time scenario we have taken the case study of some Commercial banks limited } \\
\text { within Odisha in order to understand "why" some prefer the use of ATM and some are not, } \\
\text { and how it influences the BSQ level. }\end{array}$} & $\begin{array}{c}13 \\
13 \\
3\end{array}$ \\
\hline & ;: \\
\hline & ${ }^{*}$ Corresponding Author: \\
\hline & \\
\hline
\end{tabular}

\section{INTRODUCTION}

The study presents a broad overview of the current state of the banking industry in Odisha. It then goes on to identify, how the use of ATM has become extremely popular among the customers as a convenient mode of transactions. Banks are aggressively adopting this mode. In today's intensely competitive economy, providing excellent customer service plays a vital role in a company's success and failure (Mouawad and Kleiner 1996). The advantages of using ATM have given new impetus in dimensions of service quality and banks are offering new choices to customers. How the customers are deriving more and more benefits through the introduction of new innovative technology adopted by banking industry enhancing the good $S Q$ level in order to meet their expectations. Thus the technological innovation has transformed the banking business. There have been a number of delivery platforms of electronic banking services, which are categorized as: ATMs, telephone banking, PC (home) banking, Internet banking, managed network, public access kiosk and
TV-based service (Daniel, 1994; Liao et al., 1999: Mols, 1998; Mols et al., 1999; Mols, 2000; Ramsay and Smith, 1999). In this paper, ATM is the main channel of distribution to be explored due to the increase in its popularity.

Mariappan (2006) analyzed that IT revolution has brought stunning changing in the business environment perhaps no other sector has been influenced by advances in technology as much as banking and finance, as a result, the banking pose a totally new look today. Patnaik (2004) in his paper stress upon that shared ATMs is taking place and they are mutually beneficial. More and more banks have adopted technology to deliver their services and this has resulted in: reduced costs, the creation of value added services for customers (Zhu et al., 2002), the facilitation of their employees' jobs and ultimately, the provision of self-service options for customers (Dabholkar and Bagozzi 2002). Lovelock and Wirtz (2000), identified secure and convenient location, adequate number of ATM, user-friendly 
system, and functionality of ATM. Davies et al., (1996) examined the factors that influence customers' satisfaction about ATM service quality. These factors include costs involved in the use of ATM, and efficient functioning of ATM. Al-Hawari et al. (2006) compiled a list of five major items about ATM service quality that include convenient and secured locations, functions of ATM, adequate number of machines and user-friendliness of the systems and procedures. Some studies have also identified customers' dissatisfaction with ATM service quality dimensions. Large numbers of customers are resistant to this new mode of service delivery and prefer more personalized service (Murdock andFranz, 1983). The researchers noted that customers do not like ATMs because of impersonality, vision problem, fear of technology and reluctance to change and adopt new mode of delivery of service (Stemper, 1990). Automated service quality is defined by Santos $(2003$, p235) as "the consumers' overall evaluation and judgement of the excellence and quality of e-service offerings in the virtual marketplace". Ogunsemore (1992) defined ATM as a cash dispenser which is designed to enable customers enjoys banking service without coming into contact with Bank Tellers (Cashiers). Moutinho (1992) examined relationship of dimensions of usage rate and performance expectation with customers' prolonged satisfaction with ATM services. Thu all most all previous researchers have found that reliability feature of ATM is essential to consumers' use of electronic channels of banking (Liao and Cheung, 2002; Polatoglu and Ekin, 2001). Thus, Moutinho (1992) established that ATM facility resulted in speed of transactions and saved time for customers.

\section{Odisha Banking Industry: An Overview}

Recently, banking industry in different countries has shown their interest transition in improving $S Q$ from traditional branches to electronic channels. Accordingly, many of them have relied more on EBS (Electronic Banking Services) with significant growth in electronic facilities such as Internet, computer, ATMs, telephone and mobile phones. Such trend happened in many countries, for example, in Australia, Japan, Singapore, Korea, Hong Kong, India, Indonesia. When we take the case of Odisha, the economy is predominantly agrarian and ruraloriented. The state has a fairly well spread structure of banks with one branch of commercial bank for around 17 thousand people on an average (RBI annual report, 2012). Odisha has invested enormous funds in order to increase the number of online channels and to establish the needed infrastructure. In the beginning of 90's due to the distortions in Indian economy, RBI introduced reforms in the financial and banking sector so as to promote rapid economic growth and development with stability through the process of Liberalization, Privatization and Globalization (LPG). During the post reform era especially after the period of banking liberalization new private sector and foreign banks emerged - equipped with the latest technology. So, now a day's all most all the banks have started with the concept of multi- channels, like ATMs, credit cards, debit cards, telephone/ mobile banking, internet banking, call centers, etc. with a large preference for core banking system through internet from where the whole banking operation can be controlled by saving cost and manpower on the one hand and enhancing the fast and quality effective service on the other hand to the customers. The second banking sector reforms gave much more importance to the modernization and technology up gradation than any other field. The IT Act of 1999 started the speedy process of EBanking i.e. the delivery of bank's services to the customers at their office or home by using electronic technology. Bank managers we interviewed during the course of the study are keenly aware that in today's market what they firmly believe that the success in the future rest on delivering excellent service to customers determining the performance of the banks for which they need higher and developed E-banking system at the hands of this huge technological revolution.

\section{ATM Leads To Higher SQ Level}

The banking industry in India is highly competitive. Customers always want lower costs but better service comparatively. In India, customers in the banking sector are very much aware about the BSQ (Banking Service Quality) due to the significant entry of private and foreign sector banks in to the public arena after the banking reforms during 1990s. The increase of customer satisfaction can contribute significantly to performance (Barnes and Cumby, 1995; Berry et al., 1985). They contribute to economic growth of the country by making funds available for investors to borrow as well as financial deepening in the country. But in order to survive in the competitive banking industry and to increase their financial performance banks have to improve the $B S Q$ level continuously that will satisfy their customers giving a direct boost to enhance their banking performance in all spheres. Moutinho (1992) established that ATM facility resulted in speed of transactions and saved time for customers. Shamsdouha et al., (2005) found that 24 hours service, accuracy, and convenient locations were the main predictors of customer satisfaction. Thus, customers of online services expect equal or higher levels of service quality than the customers of traditional services (Santos, 2003). In a study conducted by Colgate (2003), he has found out that customer service is the most important factor that influences satisfaction rates or levels. The increased 
Sabita Paul

use of online banking services has many advantages for both customers and banks Cabas (2001) noted investment opportunities, reduction in costs, satisfaction of customers and competitiveness as motives to install and add new ATM to the existing network. Al-Hawari (2006) argued that efficient ATM functions positively affect customers' perception of service quality. All those leads to greater $S Q$ level giving rise to higher customers' satisfaction along with greater banking performance. The present study aims to explore the current trend of ATM in Odisha i.e. how many people prefer ATM and why and to determine the major factors responsible for ATM, based on respondents' perception giving a boost to the $B S Q$ level.

\section{MATERIALS AND METHODS}

The methodology is based on a set of questionnaire developed in order to gather the data, which consists of two parts i.e. the first one is dealing with the demographic profile of respondents and the second one gives a clear picture about the attitude of each financial customer (respondents) of the bank towards their use of ATM.

\section{Sampling}

The sample population used for this study consists of any person having the account in the commercial banks within Odisha. The total sample is consisting of 300 respondents.

\section{Data Collection}

The study is based both on primary as well as on secondary data. Primary data has been collected from those persons who are having their accounts in different branches of any commercial banks, within Odisha state, by filling up a well structured questionnaire and through direct personal interview with the bank customers. Secondary data is collected from the banking journals, magazines, bank's website, SLBC annual report and from different RBI publications.

\section{RESULTS}

\section{Demographic Profile}

The demographic profile of the respondents was presented in Table 1. It is clear from the table, that out of $300,61.33 \%$ are male and $38.66 \%$ are female and most of the respondents $(30.66 \%)$ belong to 25 35 age groups. Regarding education most of the customers are qualified.
Sci. Technol. Arts Res. J., April-June 2013, 2(2): 148-152

Table 1: Demographic profile.

\begin{tabular}{lcc}
\hline Variables & No & $\%$ \\
\hline Gender & & \\
Male & 184 & 61.33 \\
Female & 116 & 38.66 \\
Age & & \\
$18-25$ & 67 & 22.33 \\
$25-35$ & 92 & 30.66 \\
$35-45$ & 82 & 27.33 \\
45 above & 59 & 19.66 \\
Education & & \\
HSC & 95 & 31.66 \\
Degree & 103 & 34.33 \\
Post Graduate & 81 & 27 \\
$\quad$ Doctorate & 21 & 7 \\
Total & $\mathbf{3 0 0}$ & $\mathbf{1 0 0}$ \\
\hline
\end{tabular}

\section{Occupational Distribution}

Occupational distributions of the respondents were shown in table 2 . Results revealed that out of total respondents $28 \%$ are students, $24.33 \%$ are self employed. $28.33 \%$ are professionals where as $19.33 \%$ are belong to the house hold group.

Table 2: Occupational distribution.

\begin{tabular}{lcc}
\hline Respondents' Category & No & \% \\
\hline Students & 84 & 28 \\
Self Employed & 73 & 24.33 \\
Professional & 85 & 28.33 \\
Household & 58 & 19.33 \\
Total & $\mathbf{3 0 0}$ & $\mathbf{1 0 0}$ \\
\hline
\end{tabular}

\section{ATM User and Non User}

The Table 3 reflects that the respondents' classification based on user and non user criteria. Out of total respondents, 186 respondents $(62 \%)$ are using ATM in their day today life and 114 customers $(38 \%)$ are the non users of ATM.

Table 3: ATM user and non user.

\begin{tabular}{lcc}
\hline Respondents & No & $\%$ \\
\hline User & 186 & 62 \\
Non user & 114 & 38 \\
Total & 300 & 100 \\
\hline
\end{tabular}


Sabita Paul

\section{Reasons to Prefer to Use ATM}

Literature finds a large number of studies that highlight the satisfaction of customers with ATMs (Moutinho and Brownlie, 1989, Wan et al., 2005; Komal and Singh, 2009; Mobarek, 2007). It is clear from the above Table 4 which reveals that $29.03 \%$ uses ATM due to its time saving nature i.e. in order to avoid long queue in banks, $17.2 \%$ like it for its faster transaction, $15.05 \%$ respondents prefer it as it is easy for them to use whereas $19.89 \%$ people are in favor of the view that it is easy for them because they don't have to search for bank every time as they can get cash or check their balance enquiry through mini statement (account statement) by using it frequently wherever there is an ATM counter. Above all $18.81 \%$ customers like it as it is having all the above criteria to meet the customers' satisfaction.

Table 4: Reasons to prefer ATM.

\begin{tabular}{lcc}
\hline ATM users & No & \% \\
\hline Time Saving & 54 & 29.03 \\
Faster Transaction & 32 & 17.2 \\
Easy to use & 28 & 15.05 \\
Easy banking anytime/ & 37 & 19.89 \\
anywhere & 35 & 18.81 \\
All of the above & $\mathbf{1 8 6}$ & $\mathbf{1 0 0}$ \\
Total &
\end{tabular}

\section{Reasons for not to Prefer ATM}

Howcroft (1991) noted that dissatisfaction among the customers is associated with frequent interruptions and breakdown of ATMs. The old age people are generally shy of use of ATM because of perceived risk of failure, complexity, security, and lack of personalized service (Moutinho, 1992). The Table 5, proves it that why they don't take a keen interest to use it. Among the nonusers of ATM, $37.71 \%$ don't use it as they don't have knowledge to operate it. About $28.07 \%$ are getting fear about the safety and security due to the ATM fraud or stolen of ATM card again because of robbery at the location of the ATM as compared to a Banking Hall. $21.05 \%$ people get frustrated due to regular failure, card jamming and breakdown of machine and $13.15 \%$ don't take an interest to use it due to its all above demerits.

Table 5: Reasons for not to prefer ATM.

\begin{tabular}{lcc}
\hline \multicolumn{1}{c}{ ATM non users } & No & \% \\
\hline No Knowledge & 43 & 37.71 \\
Lack of Security & 32 & 28.07 \\
ATM Machine problem & 24 & 21.05 \\
All of the above & 15 & 13.15 \\
Total & $\mathbf{1 1 4}$ & $\mathbf{1 0 0}$ \\
\hline
\end{tabular}

Sci. Technol. Arts Res. J., April-June 2013, 2(2): 148-152

\section{Respondents' View Regarding ATM Increases BSQ Level}

The above Table no VI, shows out of total 300 respondents maximum customers (both from users and nonusers group) admit that use of ATM leads to higher BSQ. Even it is seen that among non users group, about $51.8 \%$ agree with the view though they are not using ATM due to several reasons. Very few people are not in favor of using ATM due to the lack of knowledge and security matter.

Table 5: Respondents' view regarding ATM increases BSQ level.

\begin{tabular}{ccccc}
\hline Respondents' view & \multicolumn{2}{c}{ User } & \multicolumn{2}{c}{ Non user } \\
\hline & No & $\%$ & No & $\%$ \\
\hline ATM increases BSQ level & & & & \\
Yes & 166 & 89.2 & 59 & 51.8 \\
No & 3 & 1.61 & 21 & 18.4 \\
Can't say & 17 & 9.13 & 34 & 29.8 \\
Total & $\mathbf{1 8 6}$ & $\mathbf{1 0 0}$ & $\mathbf{1 1 4}$ & $\mathbf{1 0 0}$ \\
\hline
\end{tabular}

\section{DISCUSSION}

It is clear from the study that about $38 \%$ customers are not using ATM due to several reasons. Hence, banks should develop strategies to motivate the non- users through awareness, education, extending personalized services, and demonstrating the functions of ATMs. The banks should focus not only on the satisfaction of ATM users, but also aim at delighting them to ensure their retention. Banks should capitalize on the spread of communication technology and the theory of innovations (Marshall and Heslop, 1988). They should make commitment to redress the service failures of ATMs. There is the issue of security; a robbery is more viable at the location of the ATM as compared to any Banking Hall. Where the location of the ATM is in a secluded or isolated area, a robbery can occur. This creates a negative impact on BSQ level. So Banks have to take caution while setting up ATMs. There is not cent percent guarantee of the ATM functioning, so dependence on ATM may fail the customer at times. Though some transactions may be convenient and useful to the customers, but not all advanced transaction.

\section{CONCLUSION}

Out of total respondents more than $50 \%$ agree that it is convenient and time saving to use ATM as it acts like a "mini bank" providing cash to the needy customers at anytime, anywhere whenever and wherever there is an ATM counter. May be it is restricted to withdraw cash up to a certain limit, still then it fulfills the customers' need in order to meet their growing demand at anytime satisfying one of 
Sabita Paul

the best dimensions of BSQ level. Hence, banks should focus on important aspects of user friendliness, ATM functionality and availability of transaction receipts, security and privacy as well as frequent monitoring and maintenance of ATMs. It is clear from the study that even non users are strongly in favor of the view that ATM helps to improve the $B S Q$ along with the banking performance. Hence, this paper recommends that the Banking Industry should augment and diversify their services through ATMs. Banks should also improve ATM features to suit customers and use this medium to build a strong and a sustainable relationship with customers.

\section{REFERENCES}

Al-Hawari, M., and Ward, T. (2006). The impact of automated service quality on financial performance and the mediating role of customer retention. Journal of Financial Service Marketing 10(3): 228-43.

Blodgett, J.G., Wakefield, K.L. and Barnes, J.H. (1995). The effects of customer service on consumer complaining behavior. Journal of Services Marketing 9(4):31-42.

Cabas, M. G. (2001). A History of the Future of Banking: Predictions and Outcomes. Greenwood Publishing Group, Pp 49.

Colgate, M. (2003). relationship quality, on-line banking and the information technology gap. International Journal of Bank Marketing 21(1): 29-37.

Dabholkar, P. and Bagozzi, R. (2002). An attitudinal model of technology-based selfservice: moderating effects of consumers traits and situational factors. Journal of Academy of Marketing Science 30(3): 184201.

Daniel A. (1994). Provision of electronic banking in the UK and the republic of Ireland International. Journal of Bank Marketing 17(2): 72-82.

Davies, F., Moutinho, L., and Curry, B. (1996). "ATM users attitudes: a neural network analysis". Marketing intelligence and Planning 14(2): 26-32.

Howcraft, J.B., (1991), "Customer satisfaction in Retail Banking", Service Industry Journal, January, pp. 11-17

Komal Singh, S. (2009). Impact of ATM on Customer Satisfaction (A Comparative Study of $\mathrm{SBI}, \mathrm{ICICl} \&$ HDFC bank). Business Intelligence Journal 2(2): 27687.

Liao, Z., and Cheung, M. T. (2001); (2002). InternetBased E-Banking \& Consumer Attitudes: An Empirical Study. Information and Management 39: 283-295.

Lovelock, C. and Wirtz, J. (2000). Services marketing. People, technology, strategy. Upper Saddle River: Pearson Prentice Hall.

Mouawad, M. and Kleiner, B. (1996). New developments in customer service training. Managing Service Quality 6(2): 49-56.
Sci. Technol. Arts Res. J., April-June 2013, 2(2): 148-152

Marshall, J., and Heslop, L. (1988).Technology acceptance in Canadian retail banking: a study of consumer motivations and use of ATMs. In: Barker, T. (Eds.), Financial Services Marketing in Canada, pp.3141. IJBM, Toronto

Mols, N. (1998). The behavioural consequences of PC banking". International Journal of Bank Marketing 16(5): 195-201.

Mols, N.P. (1999); (2000). The Internet and the Banks' strategic distribution channel decisions, International Journal of Bank Marketing 17(6): 295-300.

Mariappan, V. (2006). Changing the Way of Banking in India. Vinimaya 26(2): 26-34.

Mobarek, A. (2007). E-Banking Practices and Customer Satisfaction: A Case Study in Botswana', 20th Australasian Finance \& Banking Conference 2007 Paper, Available at SSRN: http://ssrn.com/abstract= 1011112 (visited on 7th October 2009).

Moutinho, L. (1989); (1992). Customer satisfaction measurements prolonged satisfaction with ATMs. International Journal of Bank Marketing 10(7): 30-37.

Ogunsemor, A.O. (1992). Banking services: The emergence and impact of electronic banking. The Nigerian Banker, January - March, 1992

Parasuraman, A., Valarie A. Zeithaml., Leonard L. Berry (1985), A conceptual model of service quality and its implications for future research. Journal of Marketing 49:41-50.

Patnaik, S. (2004). Shared ATM: The Way Forward. IBA Bulletin, December.

Polatoglu, V.N. and Ekin, S. (2001). An empirical investigation of the Turkish consumers' acceptance of Internet banking services. International Journal of Bank Marketing 19(4): 156-165.

Ramsay, J. and Smith, M. (1999). Managing customer channel usage in the Australian banking sector. Managerial Auditing Journal 14(7): 329-338

Rugimbana, R. and Iversen, P. (1994). Perceived attributes of ATMs and their marketing implications. International Journal of Bank Marketing 12(2):30-35.

Santos, J. (2003). E-service quality: a model of virtual service quality dimensions". Managing Service Quality 13(3): 233-246.

Selvaraj, V.M. (2006). Perception of Customers Towards the Utilization of ATM Service of SBI in Tirunelveli', Banking and Insurance, Vol-3, ICFAI University Press, pp-199-212.

Stemper, R.G. (1990).The Guide to Successful Consumer Banking Strategy, John Wiley \& Sons, Chichester and Toronto.

Wan, S. and Wu, J. (2005). What drives mobile commerce? An empirical evaluation of the revised technology acceptance model. Information \& Management 42: 719-729.

Zhu, F.X., Wymer, W. Jr and Chen, I. (2002), IT-based services and service quality in consumer banking. International Journal of Service Industry Management 13(1): 69-90. 